\title{
Consumer perceptions, attitudes and acceptance of new and traditional mate tea products
}

\author{
Rossana C.B. de Godoy ${ }^{\text {a,* }}$, Rosires Deliza ${ }^{\text {b }}$, Leandro B. Gheno ${ }^{c}$, Silvana Licodiedoff ${ }^{d}$, \\ Catia N.T. Frizon ${ }^{\mathrm{d}}$, Rosemary H. Ribani ${ }^{\mathrm{d}}$, Guilherme Godoy dos Santos ${ }^{\text {e }}$ \\ a Embrapa Forestry, Estrada da Ribeira, km 111, 83.411-000, Colombo, PR, Brazil \\ b Embrapa Food Technology, Av. das Américas, 29.501, 23.020-470 Rio de Janeiro, RJ, Brazil \\ c Baldo S/A Com. Industry and Commerce, Rodovia BR $476 \mathrm{~km}$ 150, 83.900-000, São Mateus do Sul, PR, Brazil \\ ${ }^{d}$ Federal University of Paraná, Centro Politécnico-Usina Piloto A. Rua H dos Santos s/n. Jardim das Américas, 81.531-980, Curitiba, PR, Brazil \\ e Federal University of Santa Maria, Av. Roraima, 1000 - Camobi, CEP: 97105-900, Santa Maria, RS, Brazil
}

\section{A R T I C L E I N F O}

\section{Article history:}

Received 22 October 2012

Received in revised form 26 February 2013

Accepted 28 February 2013

\section{Keywords:}

Mate tea

Infusion

Consumer

Preference

Attitude

\begin{abstract}
A B S T R A C T
Consumption of teas has been increasing around the world. In Brazil, mate tea, prepared from yerba mate (Ilex paraguariensis), is the most popular tea and its popularity is increasing due to the development of new mate-based products and the increasing health consciousness of the Brazilian population. Further development of the mate market in Brazil requires accurate consumer profiling, focusing on tea drinking behavior, preferences and perceptions. We applied a questionnaire to mate tea consumers to assess their beliefs, consumption behavior, and taste preferences. We also explored the acceptability of tea made from yerba mate processed in different ways: immediately after harvest and after eight months of storage, varying the percentage of leaves and sticks. One hundred consumers evaluated six experimental samples and two commercial mate teas. Results indicated that mate was most consumed in tea bag form, followed by ice teas. The preferred flavors were natural and lemon. Most of the consumers (61\%) consumed mate with sugar, drinking it at home before bedtime. Product quality, brand and price were the most important aspects taken into account when purchasing mate. The majority of consumers were not satisfied with the products currently offered in the market, and the main criticism was poor quality and packaging. Consumers accepted all tasted samples, except the tea prepared with $100 \%$ sticks. Commercial teas were less preferred than the experimental teas, indicating that there are opportunities for further development of commercially viable mate products.
\end{abstract}

(c) 2013 Elsevier Ltd. All rights reserved.

\section{Introduction}

Infusions of the leaves of aromatic plants in hot water (tea) are drunk throughout the world. In recent years the global popularity of tea has risen dramatically, with sales increasing by over $500 \%$ in ten years in some countries (New Products Trends, 2004). This startling rise in consumption has probably been driven by various factors, including the perception of tea as a natural and healthy product, an increasing diversity of teas on the market and, more generally, globalization, affordability, trends and availability. Indeed, it has been predicted that this growth in tea products will continue into the future, especially for those products that are perceived to have specific health-related functions (Koch, Muller, De Beer, Naes, \& Joubert, 2012; Miller, 2005). Besides the investigation on such functions, sensory properties are also important issue to take into account, either to describe products (Koch, Muller, Joubert, \& Naes, 2012) or to study how a specific tea is perceived/liked by consumers (Lee \& Liao, 2009; Lee et al., 2010).

\footnotetext{
* Corresponding author. Tel.: +55 413675 5600; fax: +55 4136755601 . E-mail address: catie.godoy@gmail.com (R.C.B. de Godoy).
}

Brazil is typical of this global trend of increasing tea consumption. Tea drinking has increased considerably in recent years, becoming an almost obligatory and year-round item in the diet of Brazilian consumers as in other countries (Lee \& Liao, 2009). The main causes of this growth in popularity have been identified as the increased range of new flavors on the market and the general rise of health consciousness of Brazilians (Paula, 2010).

Although a broad range of teas are drunk in Brazil, mate tea is the most consumed (IBGE, 2008). This beverage is prepared using leaves of the plant known locally as yerba mate (Ilex paraguariensis) that has phenolic compounds with antioxidant effects (Lanzetti et al., 2012). There have been claims that ingesting mate tea can be used to treat chronic diseases such as cancer, arteriosclerosis, and diabetes (Bastos, Fornari, Queiroz, \& Torres, 2006). Mate tea has recently been highly advertised for its supposed health benefits, such as its hypocholesterolemic and hepatoprotective functions (Filip \& Ferraro, 2003), its stimulatory influences on the central nervous system and its diuretic properties (Dellacasa \& Bandoni, 2001; Gonzalez, Ferreira, Vazquez, Moyna, \& Paz, 1993).

Although traditionally drunk in the south of the country, mate tea is now used all over Brazil. Moreover, it is being increasingly drunk in 
other parts of the world, especially the United States and European countries that have experienced immigration from South America. The geographic expansion of mate tea indicates its potential for diversification into new products (Heck \& Mejia, 2007). Effective exploitation of the high commercial potential of mate tea requires carefully designed consumer profiling, focusing on tea drinking behavior, preferences and perceptions. Such profiling allows the development of more effective marketing and production strategies that match consumer needs. To our knowledge, there are currently no published studies on mate tea drinking habits, although there are studies specifically focused on black tea and green tea (Lee et al., 2010). Anecdotal and observational evidence suggests that Brazilians consume mate tea in a qualitatively different way to other teas, their behavior possibly being influenced by factors such as local temperature, cultural habits, and income.

Despite the apparent health benefits of mate tea, there are relatively few commercial brands of this product available in Brazil (Paula, 2010). Moreover, these products vary considerably in flavor, composition, color and storage time, depending on the quality of the raw material and differences in processing.

The quantity of sticks in the final product may be especially important in this respect. Ultimately, the characteristics of each brand are determined by the processing criteria adopted by each agribusiness unit. In general, only branches with a diameter smaller than $10 \mathrm{~mm}$ are processed, to avoid advanced stages of lignification. Producers believe that these branches have lower content of phenolic compounds, which could harmfully alter the flavor of the product with negative impact on consumer liking (Tamasi, Filip, Ferraro, \& Calvino, 2007). Thus, variations in leaf characteristics and processing need to be investigated since it is clearly counterproductive to market a product that is disliked by consumers, even if it has excellent chemical, physical or microbiological properties (Moskowitz, 2007).

This study aimed at investigating the effect of compositional differences of mate tea raw materials on consumer acceptability of beverages taking into account the consumer profile of mate tea drinking in Brazil.

\section{Material and methods}

\subsection{Consumer}

We conducted an exploratory research with 100 consumers in which socio-demographic characteristics and ways of tea consumption were collected. Participants were recruited from the Federal University of Paraná including students and workers used to drink mate tea. Participants were mostly women (84\%), aged from 36 to 55 years (X\% of $18-25$ years; $Y \%$ of $26-35$ years; $Z \%$ of $36-45$ years; W\% 46-55 years; and T\% older than 56 years), with a roughly equal distribution in terms of education level, i.e., primary and secondary (32\%), university (30\%) and post-graduation degree (38\%). Although the high participation of females in the study can be attributes to their higher willingness to take part in the study, it is also worth commenting that women are now responsible for purchasing decisions of most Brazilian homes (Anonymous, 2012), and they drink more tea than men (IBGE, 2011). They also answered a semistructured questionnaire to get information on consumer's perception for tea. They were asked to indicate their agreement with eight statements using a 7-point scale anchored at the edges and middle (1: totally disagree; 4: neither disagree, nor agree; 7: totally agree). The attitude statements were: tea is diuretic, tea is good for health, tea helps to lose weight, tea helps digestion, tea prevents aging, tea lowers cholesterol, tea is rich in vitamins, and tea is rich in minerals. Principal Component Analysis (PCA) was applied to investigate the main patterns in attribute perceptions of mate tea by consumers. In order to identify consumer segments with different beliefs and thoughts on mate tea, hierarchical Cluster analysis was carried out on data. This statistical analysis was performed considering Manhattan distances and average linkage.

\subsection{Yerba mate processing}

Samples of mate tea used were processed according to the following steps and description (Isolabella et al., 2010):

Harvesting: green leaves and stems of I. paraguariensis were cut $(25$ to $30 \mathrm{~cm})$.

Roasting: this process is also known as "sapeco". The green yerba mate leaves were exposed to direct fire at temperatures between 600 and $800{ }^{\circ} \mathrm{C}$ in a rotary dryer for $2 \mathrm{~min}$. The inactivation of enzymes, which occurs in this stage can preserve the color, flavor and aroma of the leaves.

Pre-drying: as above, the only difference was the temperature $\left(280{ }^{\circ} \mathrm{C} / 3 \mathrm{~min}\right)$.

Drying: the leaves were exposed to a hot air flow until a $5 \%$ of moisture was reached following the process normally used by the company, which takes about $5 \mathrm{~h}$.

Milling: the dried yerba mate leaves were grounded in a miller (Felix) to make easier the manipulation and transport.

Classification: the yerba mate was classified using a 12 mesh sieve. Aging: some samples were stored for eight months in order to acquire characteristic flavor, color and aroma.

Toasting: the crushed yerba mate was toasted at $120^{\circ} \mathrm{C} / 15 \mathrm{~min}$.

\subsection{Tea samples and preparation}

It is important to investigate the effect of different percentages of sticks/leaves and freshness on consumer liking for mate. This information may help mate tea producers to offer in the market mates that meet consumer's expectation. Similarly, it is relevant to bring to the study commercial mate teas in order to compare how the experimental samples compare to the commercial ones.

Mate teas were prepared by varying the percentage of sticks/ leaves (100\% sticks, 50:50\% leaves and sticks, and 100\% leaves) and the freshness of them (fresh: immediately after harvest, and stored: after eight months of storage) yielding six experimental tea samples. Two commercial mate teas (Com1 and Com2) were purchased in local supermarket and included in the study. Com 1 is the most important tea in the Brazilian market, and Com2 the cheapest tea. Both of them have sticks and leaves in different proportions. A total of eight teas were evaluated in this study, all of them loose tea leaf packed samples. The description of all experimental samples is shown in Table 1.

For the preparation of the experimental samples, $16 \mathrm{~g}$ of mate was added to one liter of boiling water, which was then boiled for $3 \mathrm{~min}$. The tea was filtered into a thermal bottle and kept until the beginning of the sensory test, which was carried out immediately. Commercial teas were prepared following the package directions. Beverages were kept up to $20 \mathrm{~min}$ in the bottles, and they were thrown away after that.

\subsection{Consumer acceptance}

One hundred Brazilian tea consumers participated in the acceptance test. Each consumer evaluated four samples, waited for $30 \mathrm{~min}$ and

Table 1

Description of the experimental samples used in this study.

\begin{tabular}{lllll}
\hline \multicolumn{3}{c}{$\%$ of stick/leave } \\
\cline { 3 - 5 } & & $100 \%$ sticks & $50: 50$ & $100 \%$ leaves \\
\hline \multirow{2}{*}{ Storage time } & Fresh (F) & $100 \%$ stick_F & $50: 50 \_F$ & $100 \%$ leave_F \\
& Stored (S) (8 months) & $100 \%$ stick_S & $50: 50 \_S$ & $100 \%$ leave_S \\
\hline
\end{tabular}


Table 2

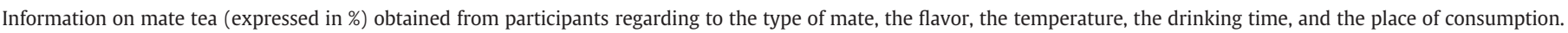

\begin{tabular}{|c|c|c|c|c|c|}
\hline Type of mate tea (\%) & Flavor-tea bag (\%) & Flavor-ice tea (\%) & Temperature of consumption (\%) & Time of drinking (\%) & Place of consumption (\%) \\
\hline Tea bags -95 & Natural-69 & Natural-29 & Hot-61 & Breakfast-36 & Home-90 \\
\hline Ice teas -48 & Peach-18 & Peach-25 & Extremely hot -7 & At meals -6 & Work-42 \\
\hline Loose tea leave packs -5 & Lemon-35 & Lemon-24 & Warm-23 & Between meals-37 & Bakery-5 \\
\hline $\begin{array}{l}\text { Natural loose tea leaves-23 } \\
\text { Instant teas-2 }\end{array}$ & Orange-11 & Orange -5 & $\begin{array}{l}\text { Cold-4 } \\
\text { Ice cold-21 }\end{array}$ & Before bedtime -90 & $\begin{array}{l}\text { Restaurant-8 } \\
\text { Not specified-4 }\end{array}$ \\
\hline
\end{tabular}

assessed the remaining four samples. Approximately $30 \mathrm{ml}$ of mate tea at $60{ }^{\circ} \mathrm{C}$ was served to consumers, coded with random three-digit numbers. The order of presentation followed a completely balanced design (MacFie, Bratchell, Greenhoff, \& Vallis, 1989) to avoid carry over effects. Consumers rated each tea for overall degree of liking using 9-point structured hedonic scales ranging from 1 (dislike extremely) to 9 (like extremely). Participants were encouraged to write comments about their opinions of each sample, so that the researcher would be able to have a better understanding of their scores. Consumers ate crackers and drank mineral water to 'clean their palates' between samples. Sugar and artificial sweeteners were provided to participants who regularly used sweetened mate. They were instructed to add the same amount of sugar (or sweeteners) in all evaluated samples. Data were analyzed using the Internal Preference Mapping and Cluster Analysis (MacFie, 2007) with the statistical software XLSTAT-MX (XLSTAT-MX, 2005). The ANOVA and the average test (Tukey $\mathrm{p}<0.05$ ) were used to verify the difference between segments. Manhattan distances and average linkage were used to carry out Cluster Analysis.

\section{Results and discussion}

\subsection{Consumer's profile}

Information from individuals of the present study on mate tea consumption according to the type of the mate, the flavor, the temperature, the drinking time, and the place where it is normally consumed is presented in Table 2. Consumers drank mates regardless of whether they were served hot or cold, were natural (not flavored with aromas), and lemon flavored (Table 2).

Most participants indicated that they typically drink mate prepared from tea bags, most frequently with sugar at home before they went to bed. Other studies have also indicated the home as the main venue to consume some beverages (Arruda et al., 2009; Endo, Bertoldi, Pinheiro, Arruda, \& Minim, 2009).

More than half of the participants (52\%) drank from 2 to 7 mate tea bags per week (6-21 g), while $37 \%$ consumed above this amount per week (Table 3). This is relatively low compared to the English tea consumer who typically drinks from 3 to 6 cups of tea a day (Posri \& MacFie, 2008). This difference in consumption is expected since tea is a traditional product for British people. Research on purchases of food and drink conducted by the IBGE (2008) indicated that the per capita consumption of mate tea in Brazil is $485 \mathrm{~g}$ per year. Coffee is the main competitor of mate tea, and its consumption is $2.200 \mathrm{~g}$ in the South of the country and $2.400 \mathrm{~g}$ in other areas (IBGE, 2008). One of the reasons for higher coffee consumption may be that this product is more closely associated with socializing (Arruda et al., 2009).

Table 3

Participants average consumption of mate tea per week (\%).

\begin{tabular}{lcll}
\hline $\begin{array}{l}\text { Tea bags } \\
(3 \mathrm{~g})\end{array}$ & $\begin{array}{l}\text { Loose tea leave packs } \\
(250 \mathrm{~g})\end{array}$ & $\begin{array}{l}\text { Ice tea } \\
(300 \mathrm{ml})\end{array}$ & $\begin{array}{l}\text { PET bottles } \\
(1.5 \mathrm{l})\end{array}$ \\
\hline$<2.0(11)$ & $1 / 2(7)$ & $1.0(18)$ & $1.0(16)$ \\
2.1 to $4.0(24)$ & $1.0(5)$ & 1.1 to $4.0(14)$ & 1.1 to $4.0(8)$ \\
4.1 to $7.0(28)$ & $>1.0(1)$ & 4.1 to $7.0(2)$ & 4.1 to $7.0(8)$ \\
$>7(19)$ & & & \\
\hline
\end{tabular}

The amount of mate ice tea consumed per week varied greatly among Brazilian respondents. About 30\% of participants informed they drink up to four glasses of $300 \mathrm{ml}$ a week, while $24 \%$ reported from 1 to 4 PET bottles of 1.51 (Table 3). Brazilian Association of Food Industries reports that the production of ice teas grew by $148 \%$ over the past 10 years (ABIA, 2010), indicating the importance of the product for the sector. A growth in this market has also been reported in other countries. In Thailand and Korea the consumption of ice teas represented $43.8 \%$ of the tea market (Lee \& Liao, 2009). In the U.S.A. the ice tea consumption frequency was between 1 and 5 times a week (Lee et al., 2010).

Besides mate tea, Brazilian consumers drink other infusions such as chamomile, lemon balm and peppermint possibly because of their alleged medicinal properties. The use of chamomile was highlighted in the study by Veiga Junior (2008), in which $60.2 \%$ of participants reported consuming it during health treatments. Research conducted by Castro et al. (2004) showed that $69.8 \%$ of mothers used mint tea, squall mint and lemon balm in the medication of their children. Studies with old people showed that $57 \%$ of them use herbal teas for health purposes (Flores \& Mengue, 2005). In relation to the consumption of black and green teas only $50 \%$ of consumers reported they consumed them.

When consumers were asked about choice factors during the purchase of mate tea, they mentioned firstly the quality, then the brand and finally the price. Lee and Liao (2009) identified the main factors influencing tea consumption as price, packaging, advertising, brand, flavor, name, ability to refresh, and sales distribution capacities.

In relation to the quality of mate teas, it has been observed that $56 \%$ of consumers were not satisfied with the mate tea products offered in the market, and the main criticism was the quality. They considered the flavor and the aroma either weak or artificial, being different from that expected from the label. Finally, the consumers reported the presence of impurities in the commercial products. The packaging, both primary (boxes), and the secondary (tea bags), was also criticized as having poor quality. They specifically indicated the fragility of the boxes, reporting that they were easy to deform and get wet. The tea bags were criticized for losing their label or cord during infusion.

Brand played an important role on consumer mate tea purchases, although it also happens with other products; e.g. around 93\% of coffee consumers choose the product by brand (Della Lucia, Minim, Silva, \& Minim, 2007). In Brazil there are only five brands that share most of the national mate tea market (Supermercado Moderno, 2009),

Table 4

Segments of consumer based on their similar perceptions on mate tea. ${ }^{a}$

\begin{tabular}{llll}
\hline & $\begin{array}{l}\text { Segment } 1 \\
(\mathrm{n}=60)\end{array}$ & $\begin{array}{l}\text { Segment 2 } \\
(\mathrm{n}=27)\end{array}$ & $\begin{array}{l}\text { Segment 3 } \\
(\mathrm{n}=13)\end{array}$ \\
\hline Diuretic & 5.8 & 4.5 & 7.0 \\
Healthy & 6.6 & 5.2 & 6.6 \\
Help lose weight & 5.1 & 3.2 & 6.8 \\
Help digestion & 6.2 & 4.2 & 7.0 \\
Prevent aging & 4.3 & 3.2 & 7.0 \\
Lower cholesterol & 4.7 & 3.8 & 6.2 \\
Rich in vitamins & 4.2 & 2.6 & 5.2 \\
Rich in minerals & 4.7 & 3.2 & 5.5 \\
\hline
\end{tabular}

a Evaluated in 7-point scales raging from 1: totally disagree to 7: totally agree. 
while medicinal teas are produced by a larger number of companies (Gomes, Negrelle, \& Rücker, 2005). Few companies controlling the market teas may reduce the competitiveness. As a consequence, we observed that consumers also complained about the prices. According to participants, the prices charged in supermarkets are extremely high when taking into account the quantity of the product supplied.

\subsection{Consumer beliefs and thoughts on mate tea}

Segmentation based on similar perceptions about mate tea (using hierarchical cluster analysis) identified three groups of consumers (Table 4) with different beliefs and attitudes about mate tea. Cluster 1 was composed of $60 \%$ of consumers; Cluster 2 had $27 \%$ of the
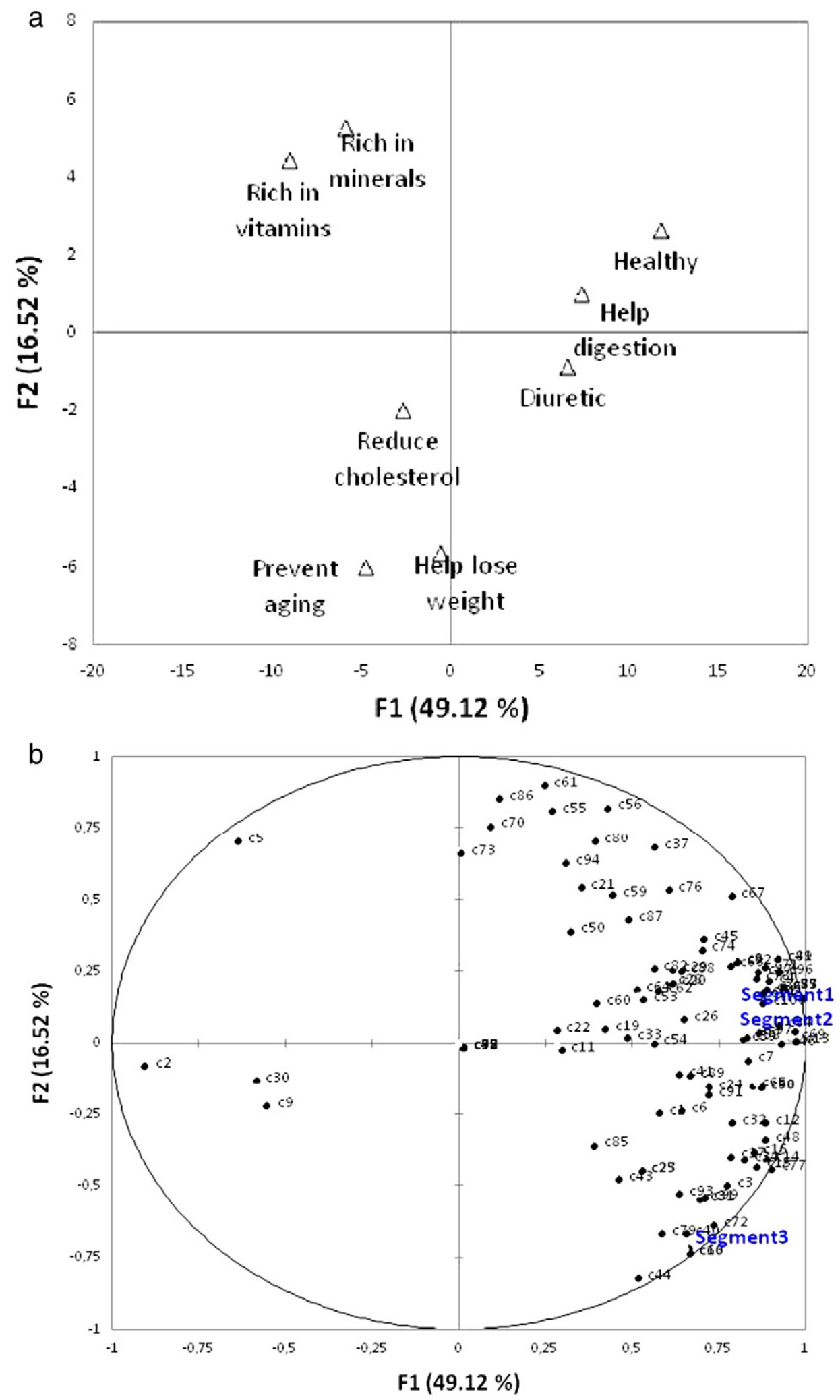

Fig. 1. Consumer perception of mate tea showing (a) mate attributes, and (b) consumers and segments of consumers. 
sample, and Cluster 3 with 13\% of the participants. The first and second components of the PCA accounted for by $65.6 \%$ of the variance (Fig. 1). These three segments differed in their beliefs and thoughts regarding mate tea, but the largest difference was between segment 3 and the other two. The former differed mainly in the belief related to the content of vitamins and minerals, and the property of lowering cholesterol.
The largest segment (1) was represented by $53 \%$ of people aged between 26 and 45 years old with different education levels. These people only believe that mate tea is diuretic, healthy and helps to lose weight. In relation to the obesity there are some studies that prove the benefits of yerba mate against the problem (Andersen \& Fogh, 2001). However, there is no strong scientific evidence that mate tea is a diuretic (Gonzatti, Mussoi, \& Fleck, 2010). In contrast,

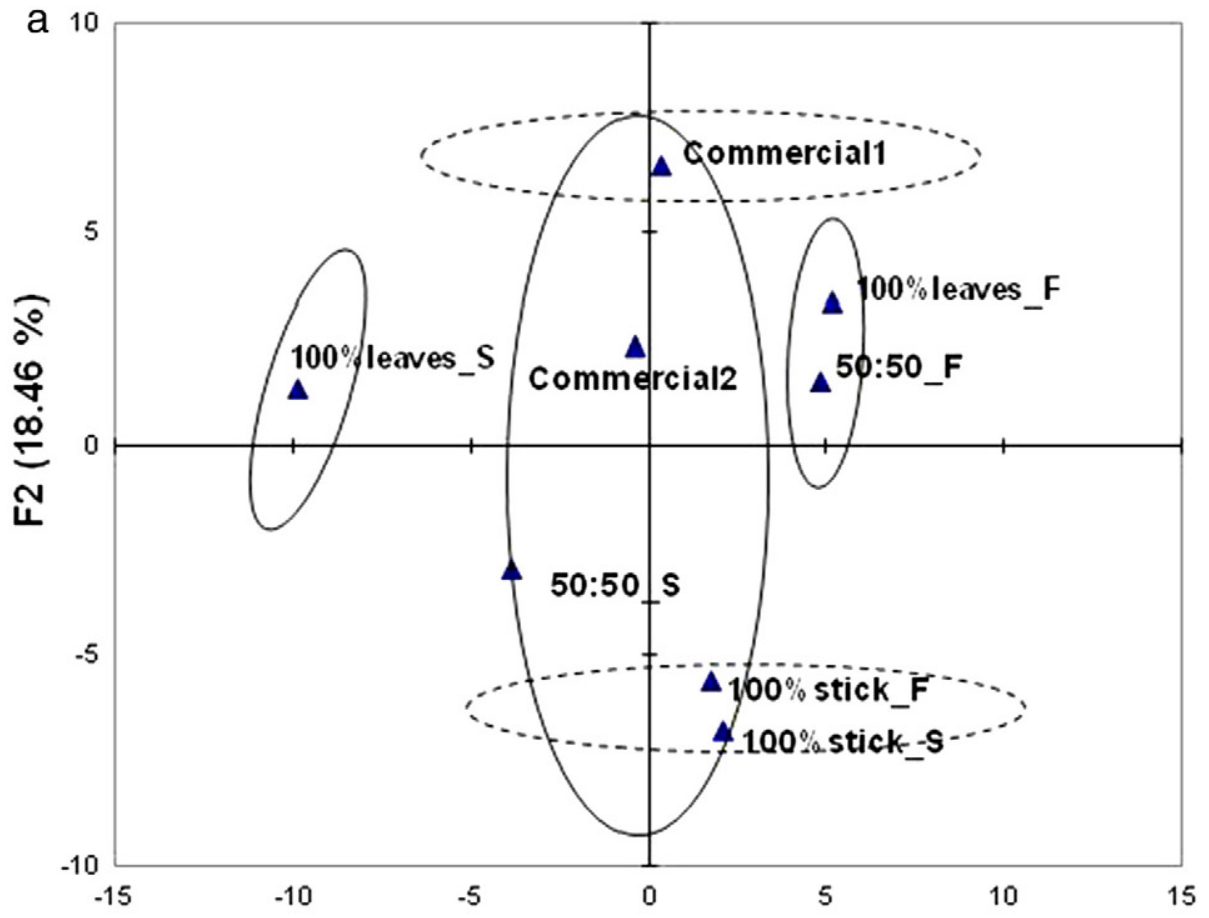

F1 $(20.78 \%)$

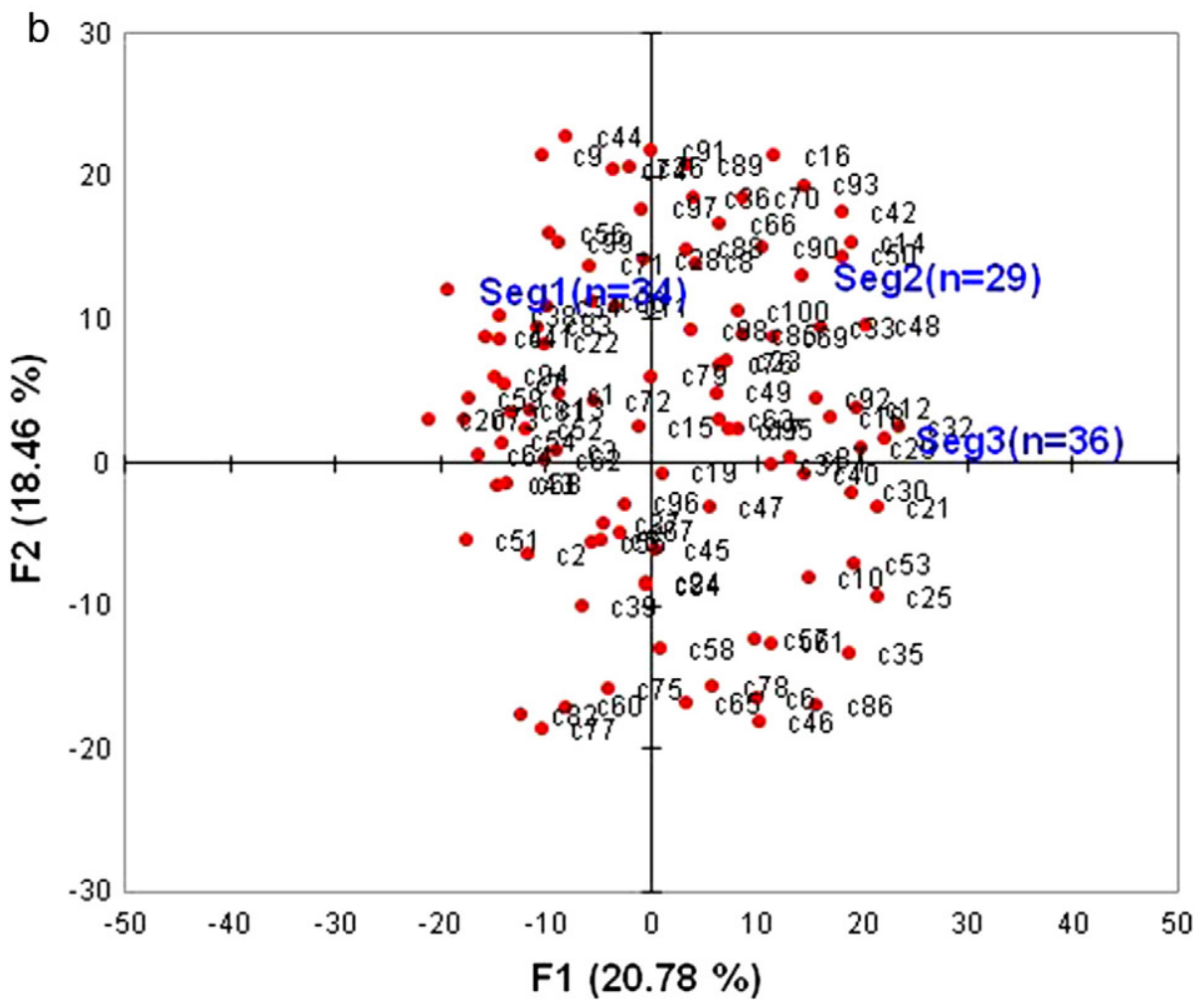

Fig. 2. Graphical representation of dimensions 1, and 2 of the preference mapping showing (a) the position of teas, and (b) consumers and segments of consumers. 
this group was apparently uninformed about other health benefits of mate consumption, such as the mate tea contributes to reduce the level of hypercholesterolemia (Melo et al., 2007) or that it contains manganese and thiamine (NEPA-UNICAMP, 2006; Wróbel, Wrobel, \& Urbina, 2000). The second segment was characterized by a higher proportion of males, and was mostly formed by older people (61\% between 36 and 56 years old) with post-graduate degrees. The people from this segment considered mate tea only as healthy. The third segment of consumers was the smallest $(n=13)$, and was not associated with a predominant age or level of education. For these people mate tea had a lot of healthy properties.

\subsection{Consumer acceptance results}

The Internal Preference Mapping shows graphically the preference of each consumer (Fig. 2), which is represented on the graphic by the end of a vector. The first three principal components accounted for by $55.74 \%$ of the total variance (20.8\% for the first component, $18.4 \%$ for the second, and $16.5 \%$ for the third one). The first component (F1) separated the mates made from fresh yerba (100\%leave_F and 50:50_F) from the others (solid line in Fig. 2a); regardless of whether it was made from leaves or sticks. It suggests that storage time had an important effect on participants' preferences, revealing that they preferred teas prepared with yerba processed soon after harvest. The two commercial teas, the stored eight-month stick (100\%stick_S), fresh stick (100\%stick_F), and the 50:50 stored eight months (50:50_S) formed the second group. Finally, there was also a clear separation of samples prepared from 100\% leaves and stored eight months (100\%leave_S). The second dimension (F2) (dotted line in Fig. 2a) separated remaining samples into commercial mate (commercial 1) and those prepared with sticks (fresh and stored: 100\%stick_F and $100 \%$ stick_S, respectively) (Fig. 2b). Most individuals in this study were located in the upper right quadrant of the map, showing a preference for commercial 1 and tea made from 100\%leaves_F and 50:50_F, both freshly processed.

Market segmentation is the process of dividing large heterogeneous markets into smaller homogeneous subgroups of people (Engel, Blackwell, \& Miniard, 2000) i.e. distinct subsets of customers with similar wants and needs (Mowen \& Minor, 2003). Females were predominant in all the segments. Brazil's population is composed by $51 \%$ of females and $49 \%$ of males (IBGE, 2010). In relation to gender influence on sensory tests studies showed that females obtained higher scores than males for many sensitivity types as bitter, sour and sweet intensity assessment (Michon, O'Sullivan, Delahunty, \& Kerry, 2009).

Consumers in segment 2 (30\% of participants) liked all samples; whereas those in segments 1 and 3 were more restricted regarding some of them (Table 5). Segment 2 did not notice significant differences between samples in relation to their preference, including the commercials. Individuals of this segment were characterized by lower education and very much driven by price, i.e., they considered price as the main factor at the moment of purchasing teas.

\section{Table 5}

Average liking ${ }^{\S}$ scores of mate tea for the three identified consumers segments.

\begin{tabular}{llll}
\hline Samples & $\begin{array}{l}\text { Segment 1 } \\
(\mathrm{n}=34)\end{array}$ & $\begin{array}{l}\text { Segment 2 } \\
(\mathrm{n}=30)\end{array}$ & $\begin{array}{l}\text { Segment 3 } \\
(\mathrm{n}=36)\end{array}$ \\
\hline Commercial 1 & $4.7^{\mathrm{cd}}$ & $6.6^{\mathrm{ab}}$ & $4.7^{\mathrm{cd}}$ \\
Commercial 2 & $4.6^{\mathrm{cd}}$ & $6.7^{\mathrm{ab}}$ & $5.1^{\mathrm{c}}$ \\
$100 \%$ leaves_S & $6.0^{\mathrm{b}}$ & $6.5^{\mathrm{ab}}$ & $3.5^{\mathrm{ef}}$ \\
$100 \%$ sticks_S & $3.0^{\mathrm{f}}$ & $6.4^{\mathrm{ab}}$ & $4.8^{\mathrm{cd}}$ \\
$50: 50 \_S$ & $4.6^{\mathrm{cd}}$ & $6.6^{\mathrm{ab}}$ & $4.6^{\mathrm{cd}}$ \\
$100 \%$ leaves_F & $3.7^{\mathrm{ef}}$ & $7.1^{\mathrm{a}}$ & $5.1^{\mathrm{c}}$ \\
$100 \%$ sticks_F & $4.1^{\mathrm{de}}$ & $6.5^{\mathrm{ab}}$ & $4.9^{\mathrm{cd}}$ \\
$50: 50 \_\mathrm{F}$ & $4.7^{\mathrm{cd}}$ & $7.0^{\mathrm{a}}$ & $6.4^{\mathrm{ab}}$
\end{tabular}

Different letters in columns imply difference between samples ( $p>0.05)$.

$\S$ Evaluated in 9-point hedonic scales, ranging from 1 (dislike extremely) to 9 (like extremely). $\mathrm{N}=100$.
The only exception for segments 1 and 3 was $100 \%$ leaves stored eight month (100\%leave_S). In general, this group of consumers aged over 35, had post-graduate degrees, and purchased high quality mate teas with well-known brands. The yerba mate can develop different flavors during storage, making difficult to predict the acceptance or rejection of the product by consumers (Surkan, Albani, \& Ramallo, 2009). Therefore, it would be valuable to evaluate consumer preferences for stored samples.

The consumer segmentation allowed us to verify that samples with low acceptance were made with yerba mate sticks, although individuals of specific groups could still appreciate them (e.g. segment 2 ). It is interesting to observe that products made only with sticks were accepted by consumers in segment 2 (mean between 6.4 and 6.5). This result is quite important for the industry of tea because the sticks (that are normally discarded) could be used in the processing of mate tea. Studies showed that the aqueous extract from sticks is weaker and can affect the taste of the product. However, Sabbatella, Pokolenko, and Schmalko (2009) reported that only $12 \%$ of the consumers were able to detect difference in the flavor of yerba mate made with different proportions of sticks. The heat treatment also can affect the sensory characteristics of teas as well the tea-making technique (Dos, Ayhan, \& Sumnu, 2005; Koch, Muller, De Beer, et al., 2012; Koch, Muller, Joubert, et al., 2012). Pagliosa et al. (2010) reported that extracts from sticks had higher levels of phenolic compounds and antioxidant activity compared to those made only from leaves.

The third segment comprised $36 \%$ of consumers and showed a preference for mate tea prepared with 50:50 (leaves: stick) processed after its harvest (50:50_F). This consumer segment mainly represents young people at the university. Most of Brazilian people (35\%) are young aged between 19 and 34 years old (IBGE, 2010).

Considering all results it is possible to say that commercial mate tea in Brazil had relatively low acceptance for the majority of consumers who participated in this study. Similar results were achieved by Lee and Liao (2009) after evaluating famous black tea brands, which also had low acceptance. The experimental samples had acceptance scores higher or equal to the commercial brands, mainly for the beverages prepared with yerba mate processed after harvest, and in the proportion of $50 \%$ leaves and $50 \%$ of sticks.

\section{Conclusions}

The results of this study point out the need for an increase in industrial investment in mate tea as a promising and versatile alternative to the development of the sector in Brazil. There is an industrial opportunity to develop the market considering that consumers reported strong dissatisfaction with the quality of mate teas currently available, especially with respect to aroma, flavor and presentation of the products (package). Marketing strategies that promote quality improvement, aiming at contributing to the increase of mate consumption should be developed by the sector. Mate teas processed with fresh yerba were liked by consumers and were frequently, but not always, perceived as superior to commercial products. The addition of up to $50 \%$ mate sticks in the product formulation did not clearly affect acceptability levels, suggesting a possible use for a by-product that is currently discarded by the industry. Despite the novelty and usefulness of the study with Brazilian consumers, it is worth mentioning that it was done with a specific population (individuals from Curitiba, a city located in the south of the country). Thus, further studies are recommended in other Brazilian cities, which have important role in relation to tea consumption.

\section{Acknowledgment}

The authors thank the company Baldo S/A Commerce and Industry for financial support and the consumers who participated in the study. 


\section{References}

ABIA. (2010). Associação Brasileira das Indústrias de Alimentação. Evolução da produção brasileira de chás prontos para beber [mensagem pessoal]. Mensagem recebida por <catie.godoy@gmail.com> em 17 fev.

Andersen, T., \& Fogh, J. (2001). Weight loss and delayed gastric emptying following a South American herbal preparation in overweight patients. Journal of Human Nutrition and Dietetics, 14, 243-250.

Anonymous (2012). Elas estão com tudo. http://www.elciofernando.com.br/blog/tag/ nielsen-brasil/page/5/ (Accessed on the 12 Feb. 2013)

Arruda, A. C., Minim, V. P. R., Ferreira, M. A. M., Minim, L. A., Silva, M. N., \& Soares, C. F. (2009). Jusficativas e motivações do consumo e não consumo de café. Ciência e Tecnologia de Alimentos, 24(9), 754-763.

Bastos, D. H. M., Fornari, A. C., Queiroz, Y. S., \& Torres, E. A. F. S. (2006). Bioactives compounds content of chimarrão infusions related of the moisture of yerba maté (Ilex paraguariensis). Brazilian Archives of Biology and Technology, 49(3), 399-404.

Castro, T. G., Campos, F. M., Priore, S. E., Coelho, F. M. G., Campos, M. T. F. de S., Franceschini, S. de C. C., \& Rangel, A. A. (2004). Saúde e nutrição de crianças de 0 a 60 meses de um assentamento de reforma agrária, Vale do Rio Doce, MG, Brasil. Revista de Nutrição, $17(2), 167-176$

Della Lucia, S. M., Minim, V. P. R., Silva, C. H. O., \& Minim, L. A. (2007). Fatores da embalagem de café orgânico torrado e moído na intenção de compra do consumidor. Ciência e Tecnologia de Alimentos, 27(3), 485-491.

Dellacasa, E., \& Bandoni, A. L. (2001). El mate. Revista de Fitoterapia, 1(4), 269-278.

Dos, A., Ayhan, Z., \& Sumnu, G. (2005). Effects of different factors on sensory attributes, overall acceptance and preference of rooibos (Aspalathus linearis) tea. Journal of Sensory Studies, 20, 228-242.

Endo, E., Bertoldi, M. C., Pinheiro, N. M. S., Arruda, A. C., \& Minim, P. R. (2009) Caracterização do mercado consumidor de "água aromatizada": hábitos e motivações para o consumo. Ciência e Tecnologia de Alimentos, 29(2), 365-370.

Engel, J., Blackwell, R., \& Miniard, P. (2000). Comportamento do consumidor (pp. 725). Rio de Janeiro: Livros Técnicos e Científicos.

Filip, R., \& Ferraro, G. E. (2003). Researching on new species of Mate: Ilex brevicuspis: phytochemical and pharmacology study. European Journal of Nutrition, 42, 50-54.

Flores, L., \& Mengue, S. S. (2005). Uso de medicamentos por idosos na região Sul do Brasil. Revista de Saúde Pública, 36(9), 924-929.

Gomes, E. C., Negrelle, R. R. B., \& Rücker, N. G. A. (2005). Acondicionamento e rotulagem de capim limão (Cymbopogon citratus (D.C.) Stapf). Visão Acadêmica, 6(1), 61-76.

Gonzalez, A., Ferreira, F., Vazquez, A., Moyna, P., \& Paz, E. A. (1993). Biological screening of Uruguayan medicinal-plants. Journal of Ethnopharmacology, 39, 217-220.

Gonzatti, C. S., Mussoi, T. D., \& Fleck, J. (2010). Efeito do consumo de chimarrão na diurese de mulheres jovens. Alimentos e Nutrição, 21(3), 385-390.

Heck, C. I., \& Mejia, E. G. (2007). Yerba mate tea (Ilex paraguariensis): a comprehensive review on chemistry, health implications, and technological considerations. Journal of Food Science, 72, 138-151.

IBGE (2008). Brazilian Institute of Geography and Statistics. www.ibge.gov.br/home/ estatistica/populacao/condicaodevida/pof/2008_2009_aquisicao/default_zip.shtm (Access on the 27 January 2010)

IBGE (2010). Brazilian Institute of Geography and Statistics. Censo demográfico 2010. Características gerais da população, religião e pessoas com deficiência $(<\mathrm{ftp}: / / \mathrm{ftp}$. ibge.gov.br/Censos/Censo_Demografico_2010/Caracteristicas_Gerais_Religiao_ Deficiencia/caracteristicas_religiao_deficiencia.pdf> Access on the 20 December 2012)

IBGE (2011). Brazilian Institute of Geography and Statistics. http://www.ibge.gov.br/home/ presidencia/noticias/noticia_visualiza.php?id_noticia=1937\&id_pagina=1 (Access on the12 February 2013)

Isolabella, S., Cogoi, L., López, P., Anesini, C., Ferraro, G., \& Filip, R. (2010). Study of the bioactive compounds during yerba mate (Ilex paraguariensis) processing. Food Chemistry, 122, 95-699.

Koch, I. S., Muller, N., De Beer, D., Naes, T., \& Joubert, E. (2012). Impact of steam pasteurization on the sensory profile and phenolic composition of rooibos (Aspalathus linearis) herbal tea infusions. Food Research International, http://dx.doi.org/10.1016/j.foodres. 2012.10.017.
Koch, I. S., Muller, N., Joubert, E., \& Naes, T. (2012). Sensory characterization of rooibos tea and the development of a rooibos sensory wheel and lexicon. Food Research International, 46, 271-228

Lanzetti, M., Barroso, M. V., Nesi, R. T., Lopes, A. A., Trajano, E. T. L., Alves, J. N., et al. (2012). Ready-to-drink matte (R) tea shows anti-inflammatory and antioxidant properties on a cigarette smoke exposure model. Food Research International, 48, 798-801.

Lee, J. Chambers, E. IV Chambers, D. H. Chun, S. S. Oupadissakoon, C \& Johnson, D. E (2010). Consumer acceptance for green tea by consumers in the United States, Korea and Thailand. Journal of Sensory Studies, 25, 109-132.

Lee, C. -W., \& Liao, C. -S. (2009). The effects of consumer preferences and perception of Chinese tea beverages and brand positioning strategies. British Food Journal, 111(1), 80-96

MacFie, H. J. H. (2007). Preference mapping and food product development. In H. J. H. Mac Fie (Ed.), Consumer-led food product development (pp. 551-592). Cambridge: Woodhead Publishing Limited.

MacFie, H. J. H., Bratchell, N., Greenhoff, K., \& Vallis, L. V. (1989). Designs to balance the effect of order of presentation and first-order carry-over effects in hall tests. Journal of Sensory Studies, 4(1), 129-148.

Melo, S. S., Nunes, N. S. I., Baumgarten, C., Tressoldi, C., Faccin, G., Zanuzo, K., et al. (2007). Efeito da erva mate (Ilex paraguariensis A. St. Hil) sobre o perfil metabólico em ratos alimentados com dietas hiperlipídicas. Alimentos e Nutrição, 18(4), 439-447.

Michon, C., O'Sullivan, M. G., Delahunty, C. M., \& Kerry, J. P. (2009). The investigation of gender-related sensitivity differences in food perception. Journal of Sensory Studies, 24, 922-937.

Miller, G. (2005). Healthy growth ahead for wellness drinks. Food Technology, 59(10), 21-26.

Moderno, Supermercado (2009). Produtos e Marcas. Supermercado Moderno, 6, 92.

Moskowitz, H. (2007). Consumer-driven concept development and innovation in food product development. In H. MacFie (Ed.), Consumer-led food product development (pp. 342-382). Cambridge: CRC Wood head Publishing Ltd.

Mowen, J. C., \& Minor, M. (2003). Comportamento do consumidor. São Paulo: Prentice Hall.

NEPA-UNICAMP (2006). Tabela brasileira de composição de alimentos Versão II. (2 ed.). Campinas: Fórmula Editora.

New Products Trends (2004). Prepared foods. "Tea time" to last for many years. www. PreparedFoods.com (Acesss in 20 August 2011)

Pagliosa, C. M., Vieira, M. A., Podestá, R., Maraschin, M., Zeni, A. L. B., Amante, E. R., et al. (2010). Methylxanthines. phenolic composition and antioxidant activity of bark from residues from mate tree harvesting (Ilex paraguariensis A. St. Hil.). Food Chemistry, 122, 173-178.

Paula, E. (2010). Que tal um pouco de chá? Disponível em. http://www.amis.org.br/ downloads/gondola/g122/Acertando_o_passo_\%5BCh\%E1s\%5D.pdf (Access in 24 January 2010)

Posri, W., \& MacFie, H. (2008). The influence of testing context on tea bag product acceptance in central location tests. Journal of Sensory Studies, 23, 835-851.

Sabbatella, O. P., Pokolenko, J. J., \& Schmalko, M. E. (2009). Influencia de la composición en la estracción de los solubles de la yerba-mate. Revista Ciencia y Tecnologia, 11, $42-47$.

Surkan, S., Albani, O., \& Ramallo, L. (2009). Influence of storage conditions on sensory shelf-life. Journal of Food Quality, 32, 58-72.

Tamasi, O. P., Filip, R., Ferraro, G., \& Calvino, A. M. (2007). Total polyphenol content and perceived astringency of yerba mate "Ilex paraguariensis" infusions. Journal of Sensory Studies, 22, 653-664.

Veiga Junior, V. F. (2008). Estudo do consumo de plantas medicinais na Região Centro-Oeste do Estado do Rio de Janeiro: aceitação pelos profissionais de saúde e modo de uso pela população. Revista Brasileira de Farmacognosia, 18(2), 308-313.

Wróbel, K., Wrobel, K., \& Urbina, E. M. C. (2000). Determination of total aluminum, chromium, copper, iron, manganese, and nickel and their fractions leached to the infusions of black tea, green tea, Hibiscus sabdariffa, and Ilex paraguariensis (Mate). Biological Trace Element Research, 78, 271-280.

XLSTAT-MX (2005). XLSTAT-PRO User's guide version 7.5.3. NY. USA: Addinsoft Inst. Inc. 